\title{
Comparative of natural zeolite - clinoptilolite elimination of metal ions/especially Cu (II) with D-Penicillamine from biological environments
}

Rudarsko-geološko-naftni zbornik

(The Mining-Geology-Petroleum Engineering Bulletin) UDC: $622: 669$

DOI: $10.17794 / \mathrm{rgn} .2021 .4 .2$

Original scientific paper

\author{
Abdollah Forughirad'; Ataallah Bahrami'; Khalil Farhadi'; \\ Anahita Fathi Azerbaijani3; Fatemeh Kazemi ${ }^{4}$ \\ ${ }^{1}$ Department of Mining Engineering, Faculty of Engineering, Urmia University - Iran. \\ ${ }^{2}$ Faculty of Chemistry, Urmia University - Iran. \\ ${ }^{3}$ Urmia Medical Science University - Iran. \\ ${ }^{4}$ Ph.D. student of mineral processing, Faculty of Engineering - University of Kashan - Iran.
}

\begin{abstract}
Clinoptilolite is used as an adsorbent to remove heavy metal cations due to its function as a molecular sieve. This molecular sieve characteristic has made it possible to study the efficiency of clinoptilolite and D-Penicillamine in a comparative way in terms of the adsorption of heavy metals (especially copper) from a biological medium. For this purpose, clinoptilolite was subjected to grinding to produce a homogenized micronized powder in two sizes with $\mathrm{d}_{90}=75$ and 150 $\mu \mathrm{m}$. Then, initial adsorption tests in an aqueous medium were performed on $10 \mathrm{ppm}$ solutions of iron, zinc, copper, cadmium and nickel cations in single cation solutions, as well as a mixture of cations. In the next step, tests were performed to evaluate the adsorption of $\mathrm{Cu}^{2+}$ on clinoptilolite under different conditions. Experiments have been performed to investigate the effect of $\mathrm{pH}$, temperature $(\mathrm{T})$, adsorbent dosage, time and cation concentration in a simulated biological medium. According to the results, clinoptilolite has a high ability to remove metal cations from aqueous solutions. The 99.71\% removal of copper cations by clinoptilolite indicates the high ability of this mineral to remove copper from any environment. In a simulated biological medium at $\mathrm{pH}=7$ and 5 , the copper adsorption rate was $98.18 \%$ and $97.45 \%$ respectively, which indicates the high ability of zeolite to absorb copper cations under biological conditions. An examination of the mass balance calculations has also shown the ability to replace clinoptilolite with penicillamine; $15 \mathrm{mg}$ of clinoptilolite removes $214 \mathrm{mg}$ of $\mathrm{Cu}$ from aqueous solutions, which is equivalent to the formation of copper-penicillamine chelate.
\end{abstract}

\section{Keywords:}

zeolite; clinoptilolite; penicillamine; metallic cations; copper; ion exchange

\section{Introduction}

The cations of lead, aluminium, mercury, copper, cadmium, nickel and arsenic are toxins from industrial wastewaters and are among the most important and dangerous environmental hazards. Due to their resilience and accumulation in living tissues, toxicity and interference with the food chain, these metals may be transmitted to living organisms and finally to humans through various ecosystems and cause detrimental effects on human health (Raikwar et al., 2008). The presence of some of these metals in small amounts is essential for the normal functioning of the body, but excessive entry into the human body will lead to poisoning. The main problem with heavy metals is that they do not metabolize but rather accumulate in body tissues (Cox, 1999). According to Table 1, the allowed amounts of these met-

Corresponding author: Ataallah Bahrami

a.bahrami@urmia.ac.ir als in the environment and the human body are shown. Since it is required to treat industrial wastewaters and effluents for the removal of heavy metals, research has been performed on the removal of heavy metals and their toxicity from the environment using various methods, such as chemical precipitation, membrane processes, ion exchange and adsorption (Andronikashvili et al., 2009; Papaioannou et al., 2005). In this regard, the use of adsorbents with adequate efficiency and economic justification, such as zeolite, has always been one of the priorities of various industries.

Zeolite (with the general chemical formula $\mathrm{M}_{2 / n} \mathrm{O} \cdot \mathrm{Al}_{2} \mathrm{O}_{a} \cdot x \mathrm{SiO}_{2} \cdot y \mathrm{H}_{2} \mathrm{O}$ ) is an aluminosilicate mineral, whose major commercial application in industry is surface adsorbent. This group of minerals, due to their special properties, such as porosity, molecular adsorption and cation exchange capacity internally and externally, are widely used in the water treatment industry as catalysts, as well as in the medical and agricultural industries. Also, some properties of zeolites, such as being 
Table 1: Allowed concentrations of heavy metals in the environment and biological environments

\begin{tabular}{|l|l|l|}
\hline Metals & $\begin{array}{l}\text { Amount in } \\
\text { water (mg/lit) }\end{array}$ & $\begin{array}{l}\text { Amount in } \\
\text { biological medium }\end{array}$ \\
\hline Lead & 0.05 & $30 \mu \mathrm{g} / \mathrm{dl}$ \\
\hline Aluminium & 0.20 & $0.15 \mathrm{mg} / \mathrm{lit}$ \\
\hline Mercury & 0.006 & $150 \mathrm{ppb}$ \\
\hline Copper & 0.05 & $150 \mathrm{mg} / \mathrm{lit}$ \\
\hline Iron & 0.05 & $8 \mathrm{mg} / \mathrm{lit}$ (per day) \\
\hline Arsenic & $10 \mathrm{ppm}$ & $50 \mu \mathrm{g} / \mathrm{dl}$ \\
\hline Cadmium & 0.01 & $0.60 \mathrm{mg} / \mathrm{lit}$ \\
\hline Nickel & 0.07 & $20 \mathrm{ng} / \mathrm{lit}$ \\
\hline
\end{tabular}

edible, antibacterial, biocompatible and non-toxic with high adsorption properties, have made it possible to be used in the manufacturing of drug carriers (Andronikashvili et al., 2009; Papaioannou et al., 2005). Zeolite has two groups of exchangeable elements or cations (such as $\mathrm{Na}$ and $\mathrm{K}$ ) and structural elements $(\mathrm{Al}, \mathrm{Si}$ ) in its structure. The presence of a group of exchangeable cations has led to its application as an adsorbent for heavy metals as well as their portability.

Studies on the pharmaceutical applications of zeolite have led to the emergence of the new application of these materials in the veterinary and pharmaceutical industries (Bruno et al., 2015). It is reported that natural zeolites (particularly clinoptilolite) are promising substrates for manufacturing slow-release drugs (Andronikashvili et al., 2009; Papaioannou et al., 2005; Pavelic et al., 2003). The biocompatibility of some natural zeolites make them good candidates for pharmaceutical applications (Bruno et al., 2015; Pavelic et al., 2003). A study has been performed on the adsorption of Tocopherol, a source of vitamin E, on natural zeolite carriers, which showed that natural zeolite has the ability to carry drugs and perform a positive function, even in acidic $\mathrm{pH}$ (Yaneva et al., 2016). Clinical and pharmaceutical studies by Lamprecht et al., (2015) demonstrate that zeolite does not cause biological trauma in the human body. Additionally, the results of a research by Gennaro et al., (2015) showed that the adsorption of drugs in the matrix of natural clinoptilolite makes it possible to transport and slowly release the prescribed amount and reduce the side effects of these drugs.

Copper is an important component in many enzymes and some copper metal proteins. The allowed amount of copper cations in the human body is 100 to $150 \mathrm{mg}$ (per adult), and an increase in this amount causes a disorder in the function of various organs of the body through the central nervous system (Dlouhy and Outten, 2013). Regulation of copper levels and its healthy transfer to species and metalloproteins will minimize its toxic effects. In short, copper regulation and involvement are for protecting it from a reaction with zinc, $\mathrm{Cu}$ superoxide dismutase (CCS) and antioxidant protein (ATOX) for copper (Kim et al., 2008). In this regard, the chelating of copper metal cations is a method of chelating metal ions to prevent biological damage. In this method, the metal chelating drug, or in other words, the chelating agent, removes the metal from the accumulated place in the body; this means that the drug reaches the desired location, chelates the metal and removes it from that organ (Flora and Vidhu, 2010). In this case, the chelating agent and the formed metal complex must be non-toxic. Penicillamine is one of the chelating agents used in the treatment of some metabolic disorders, such as Wilson's disease, cystinuria, primary biliary cirrhosis, and is prescribed as an adjunct to lead and other metal poisoning (Aaseth et al., 2015). The mechanism of action of penicillamine is by creating a negative copper balance in the body. This can be achieved by increasing the amount of copper lost in the urine or by reducing the absorption of copper from the gastrointestinal tract using zinc salt. TETA is also one of the drugs used in copper poisoning (Wang and Peng, 2010). In addition to the abovementioned cases related to the use of chemicals, studies have been conducted on the use of natural and synthetic minerals in the field of absorption of metals from the body, especially copper, and the elimination of poisoning caused by it. Due to their crystalline and porous structure, high thermal and physicochemical stabilities and unique ion exchange and molecular sieving properties, zeolitic aluminosilicates are promising carriers/substrates for the development of slow-release pharmaceuticals (Doula et al., 2002). The interaction of different metal species, such as copper, zinc and silver with zeolite active sites is studied (Iznaga et al., 2007; Sengupta et al., 2001). The absorption of metal ions - such as copper on clinoptilolite are studied thoroughly. The ion exchange reaction on copper with a hydrogen form of a clinoptilolite can be explained using the following equations (Nikashina et al., 1993), the process of ion exchange of clinoptilolite with copper cations occurs through the following reactions (Equations. 1 and 2):

$$
\begin{gathered}
\equiv \mathrm{Si}-\mathrm{OH}+\mathrm{Cu}^{2+} \rightarrow \mathrm{S}-\mathrm{OC} u^{+}+\mathrm{H}^{+} \\
\equiv 2 \mathrm{Si}-\mathrm{OH}+\mathrm{Cu}^{2+} \leftrightarrow \equiv(S-O)_{2} \mathrm{Cu}+2 \mathrm{H}^{+}
\end{gathered}
$$

The application and development of the use of natural zeolites in the pharmaceutical industry as a metal absorber in cases of poisoning with various metals, or carriers in targeted drug delivery systems is one of the valuable applications of these materials. In order to increase the efficiency of these natural materials, the aim of this study was to investigate the adsorption properties of clinoptilolite to remove metal cations from an aqueous media, especially copper cations. Natural clinoptilolite belongs to the heulandite (HEU) group - of zeolitic minerals (Alietti, 1972). In nature, sedimentary zeolitic-rich tuffs consist of a number of crystalline and non-crystalline minerals (secondary compounds), including zeolite. From a geological viewpoint, silica-rich primary rocks make zeolites with higher 
$\mathrm{Si} / \mathrm{Al}$ ratios such as clinoptilolite, ferrierite and mordenite, while primary rocks with medium or low silica produce zeolites with lower $\mathrm{Si} / \mathrm{Al}$ ratios, such as analcime, chabazite and phillipsite (Collela, 2005). In this research, due to the appropriate cation exchange capacity of clinoptilolite with copper cations, it has been equated with the dose of penicillamine as a common chelating agent for copper cations. In this regard, by optimizing the ideal conditions for increasing the adsorption effects and investigating the effect of some variables, such as $\mathrm{T}, \mathrm{pH}$, time and metal concentration, the adsorption curve for each $\mathrm{Cu}^{2+}$ cation has been investigated.

\section{Methods}

The natural zeolite sample was clinoptilolite collected from the Qizkorpi deposit with the geographical coordinates of $46^{\circ} 33^{\prime} 45^{\prime \prime} \mathrm{E}$ and $46^{\circ} 40^{\prime} 30^{\prime \prime} \mathrm{N}$, located in the

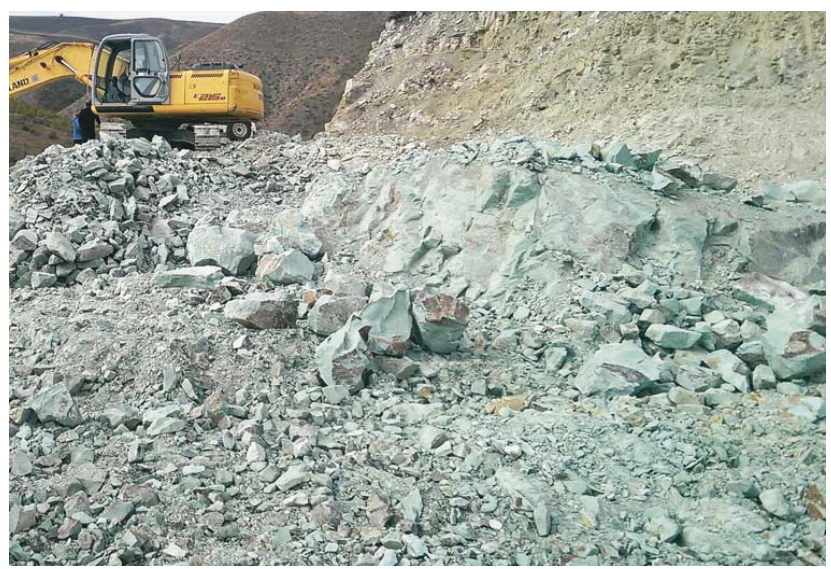

Figure 1: Zeolitic-rich tuff of Qizkorpi deposit northwest of Iran (West Azerbaijan Province). The proven reserve of the mine is more than 600 thousand tons and its annual extraction is 10 thousand tons. According to the geological studies of this deposit, the zeolitic-rich tuff is light green to light gray in color, which is formed from volcanic ash of igneous origin in the marine environment. In some cases, these materials have impurities, such as carbonate and intergranular shales due to mixing with the materials from the destruction and erosion in the sea, which are called tuffites (see Figure 1). One of the characteristics of this region is the expansion of the Permotrias organization in a considerable area. The crystalline glassy tuff of Qizkorpi, is green, fine-grained and acidic with a dacite-like composition. Also, in this mineral, the traces of feldspar and broken quartz crystals can be seen as phenoclast in the background of glass, which makes up about $80 \%$ of the rock.

The study of zeolite samples of Qizkorpi Mine shows that these materials have been strongly affected by tectonic factors. In this structure, bauxite-lateritic layers are formed and observed. On the bauxite-laterite layers, younger Tertiary sediments, including green tuffs and sandy limestones are located. These formations, which are equivalent to the Karaj Formation, were formed in the Eocene period. These tuffs are chemical sedimentary rocks and have a green-colored appearance. It is worth noting that the presence of chlorite mineral has led to the green color of the tuffs. These tuffs have accumulated as a result of repeated volcanic activity, so that a considerable thickness of them is observed in the area.

\subsection{Characterization of the zeolite samples}

In order to obtain pure samples containing the least amount of gangue, sampling of the mine was carried out

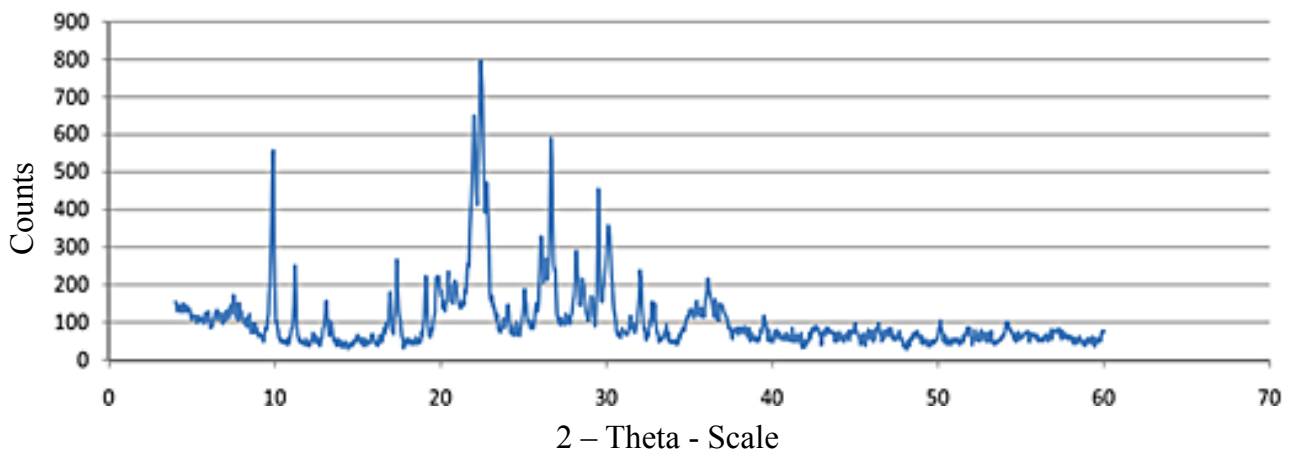

\begin{tabular}{|l|l|l|l|}
\hline Sample & Major Phase(s) & Middle Phase(s) & Minor Phase(s) \\
\hline \multirow{2}{*}{$\begin{array}{l}\text { Clinoptilolite } \\
\text { - Qizkorpi mine }\end{array}$} & $\begin{array}{l}\text { Clinoptilolite }(39-1383) \\
\mathrm{KNa}_{2} \mathrm{Ca}_{2}\left(\mathrm{Si}_{29} \mathrm{Al}_{7}\right) \mathrm{O}_{72.24} \mathrm{H}_{2} \mathrm{O}\end{array}$ & $\begin{array}{l}\text { Quartz (33-1161) } \\
\mathrm{SiO}_{2}\end{array}$ & $\begin{array}{l}\text { Calcite (05-0586) } \\
\mathrm{CaCO}_{3}\end{array}$ \\
\cline { 2 - 4 } & $\begin{array}{l}\mathrm{Heulandite}(41-1357) \\
\mathrm{Ca}\left(\mathrm{Si}_{7} \mathrm{Al}_{2}\right) \mathrm{O}_{18.6} \mathrm{H}_{2} \mathrm{O}\end{array}$ & $\begin{array}{l}\mathrm{Kaolinite}_{29-1488)} \\
\mathrm{Al}_{2} \mathrm{Si}_{2} \mathrm{O}_{5}(\mathrm{OH})_{4}\end{array}$ \\
\hline \multirow{2}{*}{$\mathrm{kV}=40$} & $\begin{array}{l}\text { Montmorillonite }(13-0135) \\
\mathrm{mA}=30\end{array}$ & & \\
& $\mathrm{Ca}_{0.2}(\mathrm{Al}, \mathrm{Mg})_{2} \mathrm{Si}_{4} \mathrm{O}_{10}(\mathrm{OH})_{2}, \mathrm{xH}_{2} \mathrm{O}$ & & \\
\cline { 2 - 4 } & $\begin{array}{l}\mathrm{Cristobalite}(39-1425) \\
\mathrm{SiO}_{2}\end{array}$ & & \\
& & & \\
\hline
\end{tabular}

Figure 2: Results of XRD analysis of zeolite sample, of Clinoptilolite type 
Table 2: Results of chemical composition analysis of zeolite sample

\begin{tabular}{|l|l|l|l|l|l|l|l|l|l|l|l|l|}
\hline Elements & $\mathbf{S i O}_{2}$ & $\mathbf{A l}_{2} \mathbf{O}_{3}$ & $\mathbf{B a O}$ & $\mathbf{C a O}$ & $\mathbf{F e}_{2} \mathbf{O}_{3}$ & $\mathbf{K}_{2} \mathbf{O}$ & $\mathbf{M g O}$ & $\mathbf{N a}_{2} \mathbf{O}$ & $\mathbf{P}_{2} \mathbf{O}_{5}$ & $\mathbf{S O}_{3}$ & $\mathbf{T i O}_{2}$ & $\mathbf{L O I}$ \\
\hline Concentration\% & 66.34 & 11.56 & 0.08 & 3.20 & 1.18 & 1.77 & 1.43 & 0.95 & 0.07 & 0.10 & 0.18 & 12.80 \\
\hline
\end{tabular}

with the hand sorting method. XRD and XRF techniques were employed to determine the crystalline phase and chemical composition of the hand-picked sample. The XRD pattern of the sample is depicted in Figure 2. Clinoptilolite, heulandite and montmorillonite are the main zeolitic phases of the hand-picked sample (HEU zeolite family) (see Figure 2). HEU is the symbol for Heulandite framework that contains the clinoptiloliteheulandite series. The ideal chemical formula of clinoptilolite is $\left((\mathrm{Na}, \mathrm{K}, \mathrm{Ca})_{2-3} \mathrm{Al}_{3}(\mathrm{Al}, \mathrm{Si})_{2} \mathrm{Si}_{13} \mathrm{O}_{36} \cdot 12 \mathrm{H}_{2} \mathrm{O}\right)$. $\mathrm{Al}$ and $\mathrm{Si}$ are known as structural elements and alkaline and alkaline earth elements are considered mobile/exchangeable cations. Heulandite is a tectosilicate mineral that belongs to the HEU zeolite family. Montmorillonite is a clay mineral with ion exchange properties. Therefore, all of the main mineral phases in the hand-picked sample have cation exchange properties.

Table 2 shows the results of chemical composition of the sample. The amount of $\mathrm{SiO}_{2}$ and $\mathrm{Al}_{2} \mathrm{O}_{3}$ in the sample were $66.34 \%$ and $11.56 \%$, respectively, which translates to $\mathrm{SiO}_{2} / \mathrm{Al}_{2} \mathrm{O}_{3}=5.73$. In the classification of HEU zeolites, samples with $\mathrm{SiO}_{2} / \mathrm{Al}_{2} \mathrm{O}_{3}>5$ are clinoptilolite.

\subsection{Study of the optical mineralogy of clinoptilolite}

The polished sections of the studied clinoptilolite were prepared to identify the associated minerals, the shape and manner of their interlocking with each other, and the degree of liberation, and were studied by a polarizing optical microscope. Based on the results, zeolite minerals are mainly present in the glass-bearing parts of the glass, which are called shard, that exist intermittently. Among these components, there are other minerals and mainly clay minerals from the group of smectite (montmorillonite), plate-like silicates such as biotite blades, scattered calcite parts, quartz crushed crystals, and rarely an albite type of feldspar. Chlorite is also seen as dispersed with montmorillonite. Unlike other minerals, the distribution of calcite in the sample is heterogeneous and its accumulations can be mentioned in some parts, along with its depletion in some other parts. In general, the sample has good purity in terms of zeolite mineral content (Forughirad, 2020).

\subsection{Clinoptilolite sample preparation}

In order to prepare clinoptilolite for metal cation absorption tests, clinoptilolite ore samples with an average particle size of $2 \mathrm{~cm}$ were crushed using a jaw crusher to a size smaller than $2 \mathrm{~mm}$. Then, the grinding process was performed using a ball mill with a ratio of grinding media to ore of 1:10 and a grinding time of 20 minutes.
Due to the sensitivity of the sample preparation (including preventing impurities from passing through devices and the test environment), the crushing steps for the production of micronized powder in an environment free of impurities and in a mill with anti-wear steel lining and balls was carried out. Using classification by standard ASTM screens, samples of micronized powder with $\mathrm{d}_{90}=75$ and $150 \mu \mathrm{m}$ were prepared. In order to remove the water in the mineral structure, clinoptilolite samples were placed in an oven at $160^{\circ} \mathrm{C}$ for 6 hours. In general, when zeolite powders are heated, due to the intensity of the $\mathrm{T}$ (temperature), several physicochemical changes occur, including the release of water molecules from their structure. The ability to release water molecules at high $\mathrm{T}$ without changing the structure of zeolites, as well as the reabsorption of water molecules from the environment at normal $\mathrm{T}$, are important features of zeolites.

\subsection{Adsorption experiments}

In this study, in order to investigate the cation exchange potential of clinoptilolite in the presence of different metals, adsorption tests have been performed on solutions containing zinc, copper, cadmium, nickel and iron metal cations. In order to measure the concentration of cations in the solution, the atomic absorption method was used by a flame atomic absorption device. Metal solutions of zinc, copper, cadmium, nickel and iron with concentrations of $2,4,6,8$ and $10 \mathrm{ppm}$ were prepared which were used to draw a calibration curve. In addition, a solution with a concentration of $10 \mathrm{ppm}$ was used to contact with the adsorbent. After contact, the adsorption of the desired cation was measured and the final concentration was obtained using the calibration curve and the adsorption percentage was reported. It is worth mentioning that samples of clinoptilolite were removed from the oven and their $\mathrm{T}$ was reduced to about ambient $\mathrm{T}$ in an autoclave, on the samples of clinoptilolite, metal cation absorption tests were performed by clinoptilolite in the following cases:

- Adsorption experiments of metal cations from metal solutions of each cation by clinoptilolite samples with $\mathrm{d}_{90}=75$ and $150 \mu \mathrm{m}$,

- Adsorption experiments of metal cations from metal solutions of each cation by clinoptilolite samples with $\mathrm{d}_{90}=75 \mu \mathrm{m}$,

- Absorption experiments of metal cation from solutions containing all cations by clinoptilolite samples with $\mathrm{d}_{90}=75 \mu \mathrm{m}$.

Also, according to the aim of this study, which is to investigate the ability of copper metal cations to be absorbed by clinoptilolite from biological media, the ability 
Table 3: The adsorption values of zinc, copper, cadmium, nickel and iron cations by clinoptilolite with different particle sizes

\begin{tabular}{|l|l|l|l|l|l|}
\hline Experiment & $\mathbf{Z n}^{2+}$ & $\mathbf{C u}^{2+}$ & $\mathbf{C d}^{2+}$ & $\mathbf{N i}^{2+}$ & $\mathbf{F e}^{3+}$ \\
\hline Clinoptilolite (Solution of all cations) & 55.84 & 40.06 & 59.15 & 56.95 & 99.30 \\
\hline Clinoptilolite (Single cation solution $\left.-d_{90}=75 \mu \mathrm{m}\right)$ & 98.90 & 99.71 & 99.02 & 97.63 & 99.30 \\
\hline Clinoptilolite (Single cation solution $\left.-d_{90}=150 \mu \mathrm{m}\right)$ & 98.90 & 99.71 & 98.78 & 97.97 & 98.59 \\
\hline
\end{tabular}

to replace zeolite clinoptilolite with D-pencillamine for copper chelating has been investigated. For this purpose, by investigating the effect of parameters such as $\mathrm{pH}$, adsorbent value, $\mathrm{T}$, time and a simulation of biological conditions, in the absorption of copper by clinoptilolite, the ability to replace this substance with D-pencillamine has been compared. The value of parameters has been selected based on the condition of biological medium and also the initial performed test. To perform each of the above experiments on a laboratory scale and in batch conditions, a $50 \mathrm{ml}$ solution of metal solution containing cations with a concentration of $10 \mathrm{ppm}$ was first prepared. Then, by applying $0.5 \mathrm{~g}$ of clinoptilolite to the solution and during the contact time of 5 minutes, the solution was filtered and finally, the amount of adsorbed elements was measured and calculated by measuring the amount of cation remaining in the solution using the atomic adsorption method (by atomic adsorption device).

\section{Results and Discussion}

\subsection{Investigating the cation exchange ability of clinoptilolite with metal ions in aqueous solutions}

The absorption of zinc, copper, cadmium, nickel and iron cations from aqueous solutions by clinoptilolite is shown in Table 3 in different cases. The ability to remove contaminant cations such as $\mathrm{Cd}^{2+}$ and $\mathrm{Ni}^{2+}$ to the values of $98.78 \%$ and $97.97 \%$, respectively, by clinoptilolite, which can be used as a suitable substrate for contamination of water samples. In general, clinoptilolite has acted as a suitable adsorbent for all cations. A notable event observed during adsorption tests was the increase in the concentration of $\mathrm{Cd}^{2+}$ and $\mathrm{Mg}^{2+}$ cations in the aqueous solution during removal, which can lead to an increase in these cations in biological samples.

While the solution contained all the zinc, copper, cadmium, nickel, and iron cations, the highest adsorption was observed for iron cations and the lowest adsorption for copper cations. The reason for the greater removal of iron can be attributed to the high charge density of this cation compared to the 2 valent cations. It is noteworthy that $0.5 \mathrm{~g}$ of clinoptilolite has been able to remove about $50 \%$ of the cations that are in the same solution together, it reveals the very high ability of this adsorbent to remove various cations, especially pollutant cations, such as $\mathrm{Ni}^{2+}$ And $\mathrm{Cd}^{2+}$ well. It should be noted that in biological environments, the values of these cations are much lower than the value taken in this study, and as a result, it is possible to confidently expect very high deletions of metallic elements in environments with low concentrations of cations.

According to Table 3, both micronized powders of clinoptilolite with $d_{90}$ values of 75 and $150 \mu \mathrm{m}$ have similar results in the absorption of zinc and copper cations. The increase in particle size in the case of nickel alone has resulted in an increase of $0.34 \%$ absorption. While in the case of iron and cadmium cations, increasing the particle size has reduced the amount of absorption. In general, based on the values presented in Table 3, it can be said that the particle size of clinoptilolite has not had a significant effect on its absorption of metal cations.

\subsection{Investigating the possibility to replace clinoptilolite with penicillamine to remove $\mathrm{Cu}^{2+}$ from biological environments}

According to the results of experiments of copper cation absorption by clinoptilolite (see Table 3), clinoptilolite removed $99.71 \%$ of the copper cations present in the solution. The absorption of heavy metals, including copper, by clinoptilolite has been the subject of various studies. According to studies, the process of ion exchange in copper absorption by clinoptilolite is very complex and occurs in two stages with rapid and slow kinetics (Nikashina et al., 1993). In general, during this process, $\mathrm{Cu}^{2+}$ cations are dissolved in aqueous solutions or hydrated by water molecules, and complex forms are formed from cations. The complexes formed to balance the negative charge due to the presence of $\mathrm{AlO}_{4}^{-}$groups in the zeolite structure are replaced. Therefore, due to the aluminosilicate structure of zeolite, which contains cation exchange centers (with a negative charge), it can be suggested as a suitable alternative to synthetic drugs, such as penicillamine in order to remove cations from biological environments. It is clear that the potential side effects of this natural ore will be much lower due to its non-dissolution in water and its high stability in living environments and, more importantly, the high rate of cation removal (Obradovic et al., 2006).

According to studies, each mole of copper cation reacts with two moles of penicillamine to form copperpenicillamine chelates. Therefore, each gram of penicillamine is expected to be able to block $214 \mathrm{mg}$ of copper. However, copper excretion from biological environments, especially in the urine sample, represents about 1\% of copper (Ahmad and Iqbal, 2017). In order to determine the amount of penicillamine used and to determine the amount of replacement zeolite, a certain 
amount of the drug was first selected and the amount of chelate formation of this compound with the drug was determined. Due to the fact that copper-penicillamine chelate is soluble in water, it is not possible to measure the amount of chelate formed by the atomic absorption method, and therefore the visible ultraviolet (UV-Vis) spectrophotometry method was used. Figure 3 shows the electron spectra of penicillamine alone and after increasing certain values of $\mathrm{Cu}^{2+}$. As can be seen, penicillamine has an absorption wavelength of about 200 nanometers, and as copper increases, the compound forms a chelate that increases its absorption wavelength to about 230 to 250 nanometers. The absorption values of most of the prepared chelate at a wavelength of $250 \mathrm{~nm}$ have been read and the absorption change diagram has been plotted according to the value added of copper (II) in Figure 4. As can be seen, the absorption values after the increase of $30 \mu \mathrm{l}$ from $\mathrm{Cu}^{2+}(0.05$ molar) are almost constant and no more chelate is formed. By extracting the curved branches, the exact amount of copper used to form the chelates was about 25 microliters of copper (II), indicating that about $3 \%$ of the copper formed with the penicillamine formed chelates. According to Figure 3 , it can be concluded that about $15 \mathrm{mg}$ of clinoptilolite can remove $214 \mathrm{mg}$ of $\mathrm{Cu}$, which is equivalent to the

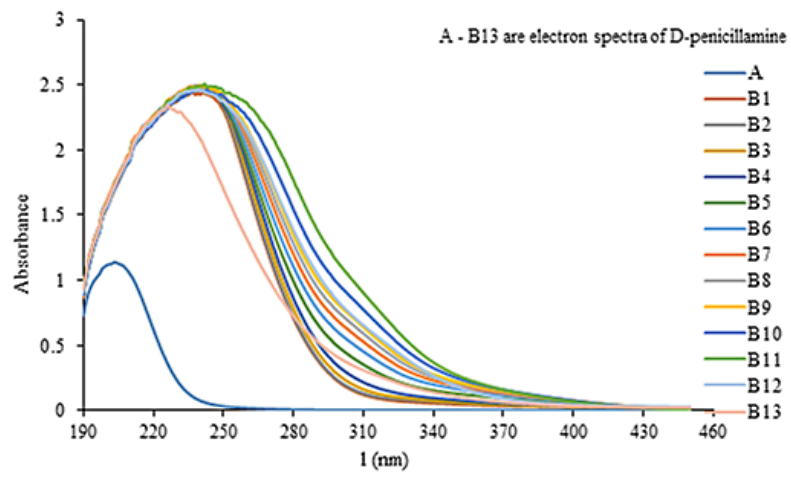

Figure 3: Electronic spectra of $75 \mathrm{mg}$ of penicillamine per $10 \mathrm{ml}$ of ionized water

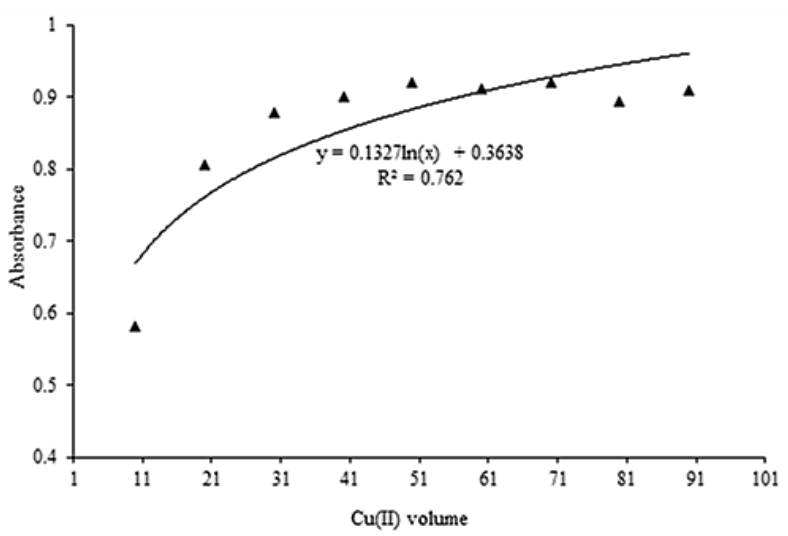

Figure 4: Diagram of adsorption changes in wavelength of $250 \mathrm{~nm}$ according to the values added of copper solution

(II) $(1.5 \mathrm{ml}$ of $75 \mathrm{mg}$ solution of penicillamine per $10 \mathrm{ml}$ of solution was titrated with microliter increases of $\mathrm{Cu}$ ) formation of copper - penicillamine chelates, from aqueous solutions.

\subsection{Investigation of the effect of effective parameters on the adsorption of copper cations by clinoptilolite}

Considering the possibility of replacing clinoptilolite with penicillamine in order to chelate copper cations, the effect of parameters with similar conditions of biological environments on the amount of copper cations by penicillamine has been investigated.

\subsubsection{The effect of solution $\mathrm{pH}$}

The relationship between the $\mathrm{pH}$ of the solution and the rate of cation absorption in the $\mathrm{pH}$ range of 5 to 7 is shown in Figure 5. The values for $\mathrm{pH}$ are selected according to the value of this parameter in the biological conditions and environment. According to the results, the highest removal rate of copper cation is $98.18 \%$ using the adsorbent clinoptilolite at $\mathrm{pH} 7$.

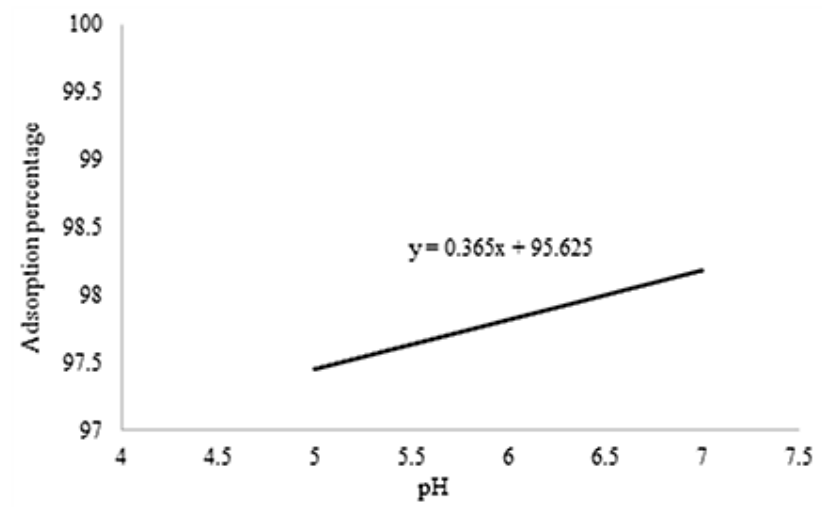

Figure 5: Effect of solution $\mathrm{pH}$ on copper cation absorption by clinoptilolite

\subsubsection{Weight of clinoptilolite}

In order to find the optimal amount of weight for clinoptilolite, different amounts of this adsorbent and with the conditions of previous experiments were placed in the vicinity of $10 \mathrm{ppm}$ copper cation solutions. The percentage of copper cation adsorption is shown by various zeolite adsorbents in Figure 6. As can be seen, the absorption rate stabilized at $0.5 \mathrm{~g}$ of zeolite and there was no increase after that. It should be noted that the ion exchange capacity of pure clinoptilolite for copper cations is equal to $2.6 \mathrm{meq} / \mathrm{g}$ (Iznaga et al., 2007). Due to the non-purity of the study sample, the absorption value for the Cu cation (more than 99\%) is more than expected. Therefore, it can be said that this issue can be caused by other substitution processes, such as copper deposition in the form of low-solubility phases or salt absorption, which increases the amount of copper adsorption (Iznaga et al., 2000). Copper precipitation is caused by the presence of $\mathrm{OH}^{-}$residual groups in the zeolite phase 
that are released during ion exchange; Their reaction with $\mathrm{Cu}^{2+}$ ions produces copper precipitate as a two-valent copper hydroxide (Iznaga et al., 2002). High absorption rates can also be attributed to the presence of other cationic minerals in the sample, such as montmorillonite and heulandite. According to the XRD analysis, the zeolite sample studied contains some of the montmorillonite and heulandite minerals, which, due to the presence of central ions in the tetrahedral and octahedral plates, have the ability to exchange ions with ions of the same or lower capacity.

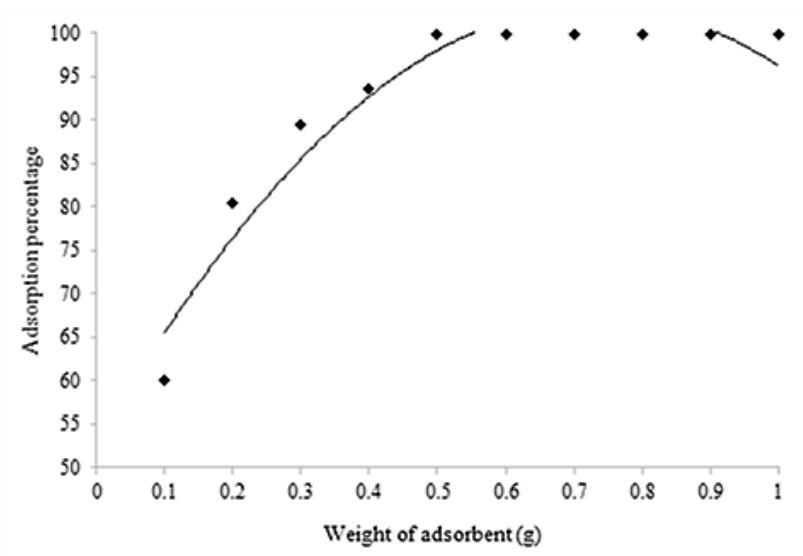

Figure 6: Comparison of the percentage of copper (II) cation absorption by different amounts of clinoptilolite

\subsubsection{Effect of $\mathrm{T}$}

Normally, the adsorption mechanism is a thermogenic process, and the rate (kinetic) of adsorption is often reduced as the $\mathrm{T}$ increases. In this study, the effect of two $\mathrm{T}$ ranges of $25^{\circ} \mathrm{C}$, the ambient $\mathrm{T}$ of laboratory experiments, and $37^{\circ} \mathrm{C}$, the biological ambient $\mathrm{T}$ (normal body temperature range $36.5-37^{\circ} \mathrm{C}$ ), were investigated with the amount of copper absorption by clinoptilolite. The results of the effect of $\mathrm{T}$ on the absorption of copper in are given in Figure 7. The maximum adsorption rate at $25^{\circ} \mathrm{C}$ is $99.71 \%$, with an increase in $\mathrm{T}$ to $37^{\circ} \mathrm{C}$, the adsorption value has decreased to $98.18 \%$. In other words,

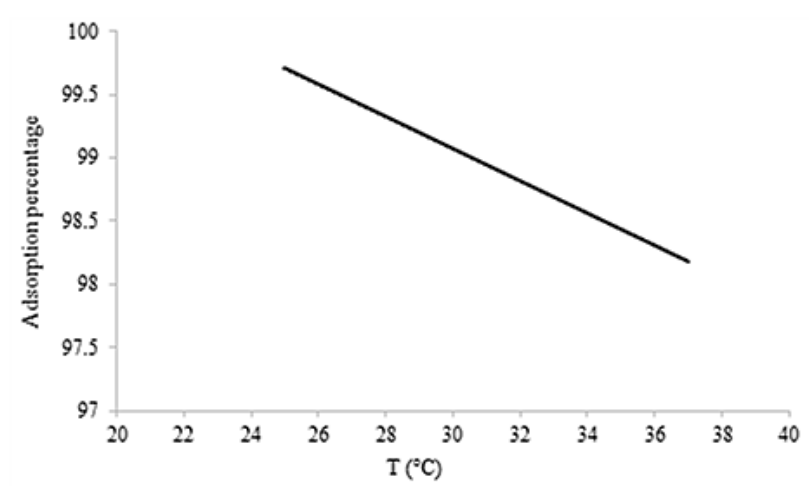

Figure 7: The effect of $\mathrm{T}$ on the adsorption of copper cations by clinoptilolite the $1.53 \%$ decrease in copper absorption was due to an increase in ambient $\mathrm{T}$ of $12 \mathrm{C}$. In general, increasing the $\mathrm{T}$ reduces the absorption of copper, and this decrease in absorption occurs in small amounts (with a gentle slope of about 7 degrees).

\subsubsection{The effect of contact time}

Due to the equilibrium property of the adsorption process, the contact time is an important parameter in achieving equilibrium in this process. The relationship between contact time and absorption percentage is shown in Figure 8. The results show that the highest removal rate of copper cation was $99.71 \%$, which was obtained by the adsorbent within 5 minutes. After that, increasing the contact time did not affect the absorption rate of $\mathrm{Cu}^{2+}$. In other words, after 5 minutes, the equilibrium in the process of cation exchange between copper and clinoptilolite is established and the passage of time will not affect the amount of absorption.

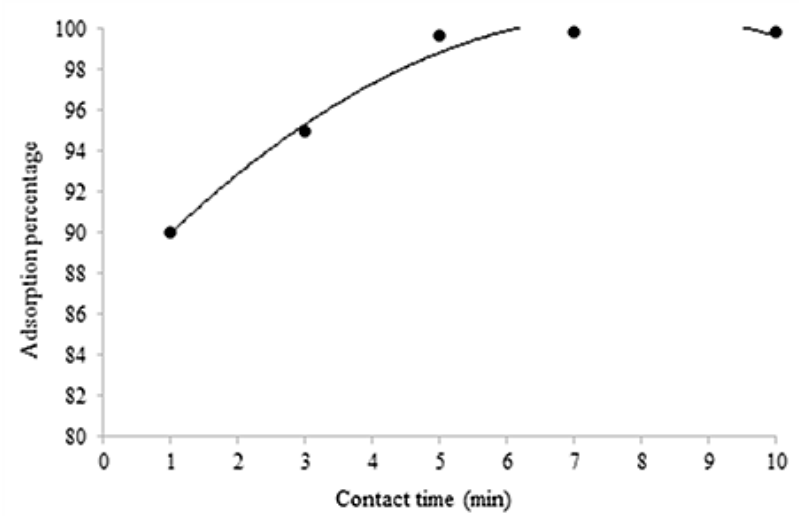

Figure 8: The effect of contact time on copper cation absorption by clinoptilolite

The study of the above parameters was in accordance with the conditions similar to blood buffer and in the stomach and for $0.5 \mathrm{~g}$ of clinoptilolite with a $10 \mathrm{ppm}$ solution of copper cation and lasted 5 minutes. The results show that in the first case with $\mathrm{pH}=7$, the copper absorption rate was $98.18 \%$, and in $\mathrm{pH}=5$, this rate was $97.45 \%$, which indicates the high ability of clinoptilolite to absorb copper cation in biological conditions and as previously mentioned, this adsorbent was expected to have a very high ability to remove metal elements from low-concentration media from copper cations (biological media).

\section{Conclusions}

Due to the unique characteristics of ion exchange, molecular sieving, adsorption and catalytic properties, the clinoptilolite type of zeolite has the potential to be used in the manufacturing of industrial adsorbents. In addition to this, clinoptilolite is marketed within the EU 
as a medical product. Therefore, the present study was performed with the aim of replacing clinoptilolite with D-Penicillamine (a drug used to absorb copper from the body). Based on this, the study concluded that the studied clinoptilolites have a high cation exchange capacity and can absorb cations of metal elements up to $99 \%$ from aquatic environments. The more than $99 \%$ removal of metal cations by clinoptilolite indicates the high ability of this mineral to remove heavy metal from an aqueous environment. The results indicate that the particle size parameter of clinoptilolite has a small effect on the adsorption rate of metal cations. In the case of adsorption of metal cations separately by clinoptilolite, the highest adsorption is related to $\mathrm{Zn}^{2+}$. However, when five cations are in the same environment, zeolites have a greater tendency to absorb $\mathrm{Fe}^{3+}$ than other cations. The reason for the greater removal of iron can be attributed to the high charge density of this cation compared to the two-valent cations.

Considering the inherent characteristics of natural zeolites, especially the type of clinoptilolite and its cation exchange ability in the above-mentioned metals, it was concluded that clinoptilolite has the potential to be used as a chelating drug to treat metal poisoning in humans and to replace the current equivalent of D-penicillamine chelating drug. Based on the results of this study, the highest percentage of removal of copper cations by zeolite was obtained at $\mathrm{pH}=7, \mathrm{~T}$ of $25^{\circ} \mathrm{C}, 0.5 \mathrm{~g}$ at $50 \mathrm{ml}$ adsorbent dosage and a contact time of 5 minutes in relation to the possibility of chelating of copper cations by clinoptilolite. The study concluded that about $15 \mathrm{mg}$ of clinoptilolite could remove $214 \mathrm{mg}$ of $\mathrm{Cu}$, equivalent to the formation of a copper D-penicillamine chelate from aqueous solutions. Finally, studies of copper removal from artificial biological environments showed that in copper - containing samples, the copper content of the samples decreased significantly.

\section{Conflict of interest}

On behalf of all the authors, the corresponding author (Ataallah Bahrami) states that there is no conflict of interest.

\section{References}

Aaseth, J., Skaug, M.A., Cao, Y., Anderson, O. (2015): Chelation in metal intoxication-principles and paradigms. Journal of Trace Elements in Medicine and Biology, 31, 260-266. https://doi.org/10.1016/j.jtemb.2014.10.001

Ahmed, M., Iqbal, M.S. (2017): Solid-state synthesis and characterization of copper-penicillamine complexes. Journal Inorganic and Nano-Metal Chemistry, 47, 6, 818-823. https://doi.org/10.1080/15533174.2016.1218508

Alietti, A. (1972): Polymorphism and crystal-chemistry of heulandites and clinoptilolites. American Mineralogist. Journal of Earth and Planetary Materials, 57, 9-10, 1448-1462.
Andronikashvili, T., Pagava, K., Kurashvili, T., Eprikashvili, L. (2009): Zeolite for Potential Toxic Metal Uptake from Contaminated Soil: A Brief. Bulletin Georgian Natural Academic, 3, 158-167. https://doi.org/10.1180/claymin. 2014.049.4.01

Bruno, D.G., Catalanotti, L., Cappelletti, P., Langella, A., Mercurio, M., Serri, C., Biondi, M., Mayol, L. (2015): Surface modified natural zeolite as a carrier for sustained diclofenac release: A preliminary feasibility study. Colloids and Surfaces B: Biointerfaces. 130, 101-109. https:// doi.org/10.1016/j.colsurfb.2015.03.052

Collela, C. (2005): Zeolites and ordered mesoporous materials: Progress and prospects. Studies in Surface Science and Catalysis, Amsterdam, 40p.

Cox, D.W. (1999): Disorders of copper transport. British medical bulletin, 55, 3, 544-55. https://doi.org/10.1258/000 7142991902619

Dlouhy, A.C., Outten, C.E. (2013): The iron metallome in eukaryotic organisms. Metallomics and the Cell Metal Ions in Life Sciences, 12p. https://doi.org/10.1007/978-94-0075561-1_8

Doula, M., Ioannou, A., Dimirkou, A. (2002): Copper adsorption and $\mathrm{Si}, \mathrm{Al}, \mathrm{Ca}, \mathrm{Mg}$, and $\mathrm{Na}$ release from clinoptilolite. Journal of Colloid and Interface Science, 245, 2, 237-250. https://doi.org/10.1006/jcis.2001.7961

Flora, S.J.S., Vidhu, P. (2010): Chelation in metal intoxication. Journal of Environ Res Public Health, 7, 7, 2745-2788. https://doi.org/10.3390/ijerph7072745

Foroughirad, A. (2020): Purification of natural Zeolite-Clinoptilolite as a carrier for chelating agent D-penicillamine. Master of Science thesis in minerals processing, Urmia University, 93p.

Gennaro, B.D., Catalanotti, L., Cappelletti, P., Langella, A., Mercurio, M., Serri, C., Biondi, M., Mayol, L. (2015): Surface modifed natural zeolite as a carrier for susained diclofenac release: a preliminary feasibility study. Colloids and Surfaces B: Biointerfaces, 130, 101-109. https://doi. org/10.1016/j.colsurfb.2015.03.052

Iznaga, I.R., Rodríguez Fuentes, G., Benítez Aguilar, A. (2000): The role of carbonate ions in the ion-exchange $\mathrm{Ni}^{2+}=2 \mathrm{NH}^{4+}$ in natural clinoptilolite. Microporous and Mesoporous Materials, 41, 1, 129-136. https://doi.org/ 10.1016/S1387-1811(00)00280-8

Iznaga, I.R., Gómez, A., Rodríguez Fuentes, G., Benítez Aguilar, A., Serrano Ballan, J. (2002): Natural clinoptilolite as an exchange of $\mathrm{Ni}^{2+}$ and $\mathrm{NH}^{4+}$ ions under hydrothermal conditions and high ammonia concentration. Microporous and Mesoporous Materials, 53, 1-3, 71-80. https://doi. org/10.1016/S1387-1811(02)00325-6

Iznaga, I.R., Petranovskii, V., Fuentes, G.R., Mendoza, C., Aguilar, A.B. (2007): Exchange and reduction of $\mathrm{Cu}^{2+}$ ions in clinoptilolite. Journal of colloid and interface science, 316, 2, 877-886. https://doi.org/10.1016/j.jcis.2007.06.021

Kim, B.E., Nevitt, T., Thiele, D.J. (2008): Mechanisms for copper acquisition, distribution and regulation. Natural chemical Biology, 4, 3, 176-185. https://doi.org/10.1038/ nchembio. 72

Lamprecht, M., Bogner, S., Steinbauer, K., Schuetz, B., Greilberger, J.F., Leber, B., Wagner, B., Zinser, E., Petek, T., 
Wallner-Liebmann, S. (2015): Effects of zeolite supplementation on parameters of intesinal barrier integrity, inflammation, redoxbiology and performance in aerobically trained subjects. Journal of the International Society of Sports Nutrition, 12, 1-11. https://doi.org/10.1186/ s12970-015-0101-z

Nikashina, V.A., Galkina, N.K., Komarova, J.V., Anfilov, B.G., Agrin, M.A. (1993): Evaluation of clinoptilolite-rich tuffs as ion-exchangers. Natural Zeolites, 93, 289-297.

Obradović, S., Adamović, M., Vukasinović, M., Jovaović, R., Levic, J. (2006): The application effects of natural Zeolite in feed and water on production results of Oncorhynchus mykiss (Walbaum). Romanian Biotechnological Letters, 11, 6, 3005-3013.

Papaioannou, D., Katsoulos, P.D., Panousis, N., Karatzias, H. (2005): The role of natural and synthetic zeolites as feed additives on the prevention and/or the treatment of certain farm animal diseases: A review. Microporous and mesoporous materials, $84,1-3,161-170$. https://doi.org/10.1016 /j.micromeso.2005.05.030
Pavelic, K., Hadzija, M., Auerbach, S.M., Carrado, K.A., Dutta, P.K. (2003): Handbook of Zeolite Science and Technology. Marcel Dekker, New York, 1143p.

Raikwar, M.K., Kumar, P., Singh, M., Singh, A. (2008): Toxic effect of heavy metals in livestock health. Veterinary World, 1, 1, 28-30.

Sengupta, D., Adams, J.B., Schneider, W.F., Hass, K.C. (2001): Theoretical analysis of $\mathrm{N}_{2} \mathrm{O}$ to $\mathrm{N}_{2}$ conversion during the catalytic decomposition of $\mathrm{NO}$ by $\mathrm{Cu}$-zeolites. Catalysis letters, 74, 3, 193-199. https://doi.org/10.1023/A:101664 1319587

Wang, S., Peng, Y. (2010): Natural zeolites as effective adsorbents in water and wastewater treatment. Chemical Engineering Journal, 156, 1, 11-24. https://doi.org/10.1016/j. cej.2009.10.029

Yaneva, Z., Georgieva, N., Staleva, M. (2016): Development of D, L- $\alpha$-tocopherol acetate/zeolite carrier system: equilibrium study. Monatshefte für Chemie-Chemical Monthly. 147, 1167-1175. https://doi.org/10.1007/s00706-016$1714-\mathrm{x}$

\section{SAŽETAK}

\section{Usporedba prirodnih zeolita (klinoptilolita) kod eliminacije metalnih iona, s naglaskom na eliminaciju Cu(II) D-penicilaminom iz bioloških okoliša}

Klinoptilolit se koristi kao adsorbent za odstranjivanje kationa teških metala djelujući kao molekularno sito. To djelovanje omogućuje izučavanje uspješnosti klinoptilolita i D-penicilamina kod adsorpcije teških metala, posebno bakra, iz biološkoga okoliša. U pokusu je klinoptilolit bio samljeven do razine homogenoga, mikronskoga praha, s česticama dvaju promjera $\mathrm{d}_{\mathrm{oo}}=75 \mathrm{i} 150 \mu \mathrm{m}$. Uslijedio je inicijalni adsorpcijski test u vodenome mediju uporabom otopine kationa željeza, cinka, bakra, kadmija i nikla od 10 ppm. Korištene su otopine s jednim kationom i više njih. Zatim je procijenjena adsorpcija $\mathrm{Cu}^{2+}$ na klinoptilolitu u različitim uvjetima. Istražen je utjecaj $\mathrm{pH}$, temperature (T), količine adsorbenta, vremena te koncentracije kationa, sve u simuliranim biološkim medijima. Klinoptilolit ima visoku sposobnost odstranjivanja metalnih kationa iz vodene otopine. Uklanjanje bakra u vrijednosti 99,71 \% upućuje na veliki potencijal odstranjivanja. Varijacijom $\mathrm{pH}=5$ i 7 adsorpcijski iznos bio je 97,45 i 98,18 \%, što je ponovno uputilo na to da zeoliti dobro adsorbiraju kation bakra u biološkim uvjetima. Načinjen je izračun bilance mase kao potvrda učinkovitosti postupka i u slučajevima kada se klinoptilolit zamijeni s penicilaminom. Tada $15 \mathrm{mg}$ klinoptilolita odvaja $214 \mathrm{mg}$ bakra iz vodene otopine tako da se stvara bakrov-penicilaminov kelat.

\section{Ključne riječi:}

zeolit, klinoptilolit, penicilamin, metalni kationi, bakar, ionska zamjena

\section{Author's contribution}

Abdollah Forughirad (MSc student of mineral processing) performed tests, analyses and provided reports. Ataallah Bahrami (Associate Professor, minerals Processing) proposed the idea and guided research. Khalil Farhadi (Professor, Chemistry) proposed the idea and guided research. Anahita Fathi Azerbaijani (Associate Professor, Medical science) provided the medical analysis and presentation of the results. Fatemeh Kazemi (PhD student of mineral processing) performed tests, provided reports and wrote the article. 